7. Levi, A. J., Gatmaitan, Z., and Arias, I. M.: Two hepatic cytoplasmic protein fractions, $\mathrm{Y}$ and $\mathrm{Z}$ and their possible role in the hepatic uptake of bilirubin, sulfobromophthalein, and other anions. J. Clin. Invest., 48: 2156 (1969).

8. Moore, C. L.: Gramicidin induced ion transport in brain mitochondria preparations. J. Neurochem.. 15: 883 (1968).

9. Odell, G. B.: Studies in kernicterus. The protein binding of bilirubin. J. Clin. Invest., 38: 823 (1959).

10. Weinbach, E. C., and Garbus, J.: Restoration by albumin of oxidative phosphorylation and related reactions. J. Biol. Chem., 24l: 169 (1966).

11. Zetterstrom, R., and Ernster, L.: Bilirubin, an uncoupler of oxidative phosphorylation in isolated mitochondria. Nature, 178: 1335 (1956).
12. Rochester, N, Y

13. St. Louis, Mo.

14. Yellow Springs Instrument Co., Yellow Springs, Ohio,

15. Dr. C. L. Moore is affiliated with the Department of Neurology. Albert Einstein College of Medicine.

16. This research was supported by United States Public Health Service Grants AM 2015, AM 5384, and AM 17702 .

17. Requests for reprints should be addressed to: Irwin M. Arias, M.D., Alber Einstein College of Medicine, Department of Medicine, 1300 Morris Park Ave., Bronx, New York 10461 (USA).

18. Accepted for publication July 25, 1975.
Hypoglycemia ketoacidosis ketotic hypoglycemia 2-methylcitrate methylmalonic aciduria propionic aciduria

\title{
Effect of 2-Methylcitrate on Citrate Metabolism: Implications for the Management of Patients with Propionic acidemia and Methylmalonic aciduria
}

\author{
SURINDER CHEEMA-DHADLI, ${ }^{(36)}$ CLIFFORD C. LEZNOFF, AND MITCHELL L. HALPERIN \\ Department of Medicine, University of Toronto, Toronto, and Department of Chemistry, York University, \\ Downsview, Ontario, Canada
}

\section{Extract}

2-Methylcitrate was tested in vitro on enzymes which interact with citrate and isocitrate. It was found to inhibit citrate synthase, aconitase, the $\mathrm{NAD}^{+}$- and $\mathrm{NADP}^{+}$-linked isocitrate dehydrogenase. This inhibition was competitive in nature except in the case of aconitase, and the $K_{i}$ for all the enzymes was in the range of 1.5-7.6 $\mathrm{mM}$. Phosphofructokinase was also inhibited by 2 -methylcitrate with $50 \%$ inhibition achieved at $1 \mathrm{mM}$. ATP-citrate lyase and acetyl-CoA carboxylase were not inhibited by this compound. 2-Methylcitrate was not a substrate for ATP-citrate lyase. Acetyl-CoA carboxylase was activated by 2 -methylcitrate with a $\mathrm{K}_{\mathrm{a}}$ of $2.8 \mathrm{mM}$. The apparent $\mathrm{K}_{\mathrm{m}}(3.3 \mathrm{mM})$ for 2-methylcitrate for the mitochondrial citrate transporter was about 10 -fold higher than the apparent $K_{m}(0.26 \mathrm{mM})$ for citrate. The tricarboxylate carrier can also be inhibited by low concentrations $(0.2 \mathrm{mM})$ of 2 methylcitrate when the concentration of citrate is close to the apparent $K_{m}$. Accumulation of 2-methylcitrate inside the mitochondrion, therefore, might lead to inhibition of enzymes in the citric acid cycle and thereby contribute to the ketogenesis and hypoglycemia seen under these conditions.

\section{Speculation}

Treatment of patients with propionic aciduria and methylmalonic aciduria with alkali therapy would be advantageous with respect to the acidemia but also would cause a more rapid exit of 2 -methylcitrate from the mitochondrion. Alkalinization with sodium citrate might be even more beneficial if this citrate could enter the liver and allow more rapid removal of 2 -methylcitrate and methylmalonate from liver mitochondria since increased cytosolic levels of these intermediates would facilitate more rapid diffusion to the extracellular space and eventual excretion in the urine. This therapy does not exclude the low protein diet and for the vitamin-responsive form of methylmalonic aciduria, $B_{12}$ treatment.

In patients with propionic and methylmalonic acidemias, 2methylcitrate has been found in the urine in substantia! quantities (1). Propionyl-CoA accumulates in liver mitochondria as a result of a deficiency of one of the enzymes required for its conversion to succinyl-CoA. 2-Methylcitrate could be formed in the mitochondrion, for example, by condensation of propionyl-CoA with oxaloacetate, despite the fact that propionyl-CoA is a poor substrate for this enzyme (26). This study was undertaken to determine whether high concentrations of 2-methylcitrate could account for any of the metabolic abnormalities found in patients with these disorders. Therefore, the effect of 2-methylcitrate was studied on the enzymes and mitochondrial transport system known to be involved in the intermediary metabolism of citrate.

The movement of citrate from the mitochondrial to the cytosolic compartment on the tricarboxylate carrier subserves several important functions in the pathway of fatty acid synthesis. It is the major pathway for two-carbon unit flow from mitochondria to cytosol (17). In addition, citrate in the cytosol could contribute to regulation of acetyl-CoA carboxylation $(9,20)$. Operation of the mitochondrial citrate transporter ( $L$-malate entry in exchange for mitochondrial citrate (4)) in conjunction with malate dehydrogenase and ATP-citrate lyase will also account for inward transport of cytosolic reducing power on NADH produced during the glycolytic sequence. Citrate is also an inhibitor of phosphofructokinase (5). More recently, an important regulatory role for mitochondrial citrate has been suggested in that this metabolite, in its free form. specifically inhibits pyruvate dehydrogenase phosphatase $(5,7)$. Regulation of the tricarboxylate carrier $(7,11,12,25)$ could be one 
of the factors influencing the mitochondrial and cytosolic citrate levels.

\section{MATERIALS AND METHODS}

Livers were obtained from male Wistar rats (110-150 g (28)). The rats were allowed free access to food before being killed $(1,000$ hr). The methods employed for the isolation and loading of mitochondria with $\left[{ }^{14} \mathrm{C}\right]$ citrate as well as those for calculating the citrate exchanges were those of Robinson et al. (22-24). 1,2,3Tricarboxybenzene $(50 \mathrm{mM})$ was used for the "inhibitor stop" experiments. In order to study the kinetics of transport of 2-methylcitrate on the tricarboxylate carrier, this agent was used in the absence of $\left[{ }^{12} \mathrm{C}\right]$ citrate, whereas to demonstrate inhibition of this carrier, 2-methylcitrate was added in the presence of $\left[{ }^{12} \mathrm{C}\right]$ citrate.

Preparation and assay of enzymes from rat liver as well as liquid scintillation counting procedures were as described previously (5). Protein was measured by the technique of Lowry et al. (18) and citrate was determined by fluorometric analysis (19).

Enzymes, metabolic intermediates, and cofactors were obtained from Boehringer Mannheim (29). Rotenone, antimycin A, and dithiothreitol were from Sigma Chemical Co. (30). 1,2.3-Tricarboxybenzene was from $\mathrm{K} \& \mathrm{~K}$ Laboratories (31). Sodium $\left[{ }^{14} \mathrm{C}\right] \mathrm{bi}$ carbonate was from Amersham/Searle (32).

\section{PREPARATION AND CRYSTALLIZATION OF 2-METHYLCITRIC ACID}

The nuclear magnetic resonance spectrum was determined using a Varian A60 spectrometer and ${ }^{2} \mathrm{H}_{2} \mathrm{O}$ as solvent. Sodium 2,2dimethyl-2-silapentane- 5 sulfonate $(\delta=0 \mathrm{ppm})$ was used as an internal reference.

The trisodium salt of 2-methylcitric acid was obtained according to the method of Habicht and Schneeberger (10). To obtain the free acid an aqueous solution of $1.0 \mathrm{~g}$ trisodium 2-methylcitrate was poured over a column of Dowex $50 \mathrm{~W}-\mathrm{X} 8$ (acid form) ion exchange resin. Evaporation of the aqueous eluent gave 2 -methylcitric acid as an oil (10). The oil was allowed to stand for 2 days at room temperature during which time crystallization had commenced. The addition of a small amount $(1 \mathrm{ml})$ of ether and subsequent scratching with a glass rod gave a crystalline mass.

Filtration gave $124 \mathrm{mg}$ pure 2-methylcitric acid (melting point $145^{\circ}-146^{\circ}$ ), obtained for the first time as a crystalline solid. The mother liquors were evaporated to give an oil, which on further standing for $24 \mathrm{hr}$ partially crystallized to a solid mass. The residue was again taken up in a small volume of ether $(1 \mathrm{ml})$ and a further crop of $84 \mathrm{mg} 2$-methylcitric acid (melting point $144^{\circ}-146^{\circ}$ ) was obtained.

The nuclear magnetic resonance spectrum of 2-methylcitric acid showed a doublet at $1.25 \mathrm{ppm}(3 \mathrm{H}, \mathrm{J}=7.2)(15)$ and a multiplet centered at $2.98 \mathrm{ppm}(3 \mathrm{H})$. The spectrum is entirely consistent with the assigned structure (16).

The mother liquors obtained from the crystallization of 2 methylcitric acid contained essentially pure 2-methylcitric acid as an oil. The nuclear magnetic resonance spectral evidence suggests that the crystalline 2-methylcitric acid is a pure diastereomeric compound, whereas the oil remaining from the crystallization is a mixture of the diastereomers of 2-methylcitric acid.

\section{RESULTS}

In all of the experiments, only the crystalline rather than the oil form a 2-methylcitrate had significant effects on the enzymes and transporter studied.

\section{EFFECT OF 2-METHYLCITRATE ON ENZYMES INFLUENCED BY CITRATE (TABLE I)}

2-Methylcitrate is an inhibitor of citrate synthase, aconitase, the $\mathrm{NAD}^{+}$- and $\mathrm{NADP}^{+}$-linked isocitrate dehydrogenases. This inhibition is competitive in nature except in the case of aconitase. The
$\mathrm{K}_{\mathrm{i}}$ for all of these enzymes is in the range of 1.6-7.6 $\mathrm{mM}$. This compound, like citrate, is an inhibitor of phosphofructokinase: $50 \%$ inhibition was achieved with $1 \mathrm{mM}$ 2-methylcitrate, whereas $3.9 \mathrm{mM}$ citrate was required to achieve this degree of inhibition of phosphofructokinase under similar conditions (5). Pyruvate dehydrogenase was not inhibited by 2 -methylcitrate in contrast to the effect of citrate (5). 2-Methylcitrate did not inhibit the cytosolic lipogenic enzymes. ATP-citrate lyase or acetyl-CoA carboxylase. and, in fact, 2-methylcitrate is a more potent activator of acetyl-CoA carboxylase than is citrate $\left(\mathrm{K}_{\mathrm{a}} \sim 6.7 \mathrm{mM}\right.$ for citrate). 2-Methylcitrate was not a substrate for ATP-citrate lyase (Table 1).

\section{EFFECT OF 2-METHYLCITRATE ON MITOCHONDRIAL CITRATE TRANSPORTER (TABLE 2)}

To study the mitochondrial citrate transporter, mitochondria were isolated from rat liver and loaded with $\left[{ }^{14} \mathrm{C}\right]$ citrate $(23)$. The $\left[{ }^{14} \mathrm{C}\right]$ citrate remained largely within the mitochondria until a counter transporting anion was added to the extramitochondrial space $(23,24)$. Although L-malate is the physiologic substrate for this transporter, citrate was chosen instead because it avoids the possibility of electrical or $\mathrm{pH}$ gradients which would be expected with the dicarboxylate anion, L-malate. In the experiments reported herein, the counter transporting anion was $\left[{ }^{12} \mathrm{C}\right]$ cit rate or 2-methylcitrate. The apparent $\mathrm{K}_{m}$ for citrate for the tricarboxylate carrier of rat liver mitochondria from normal fed rats was 0.26 $\mathrm{mM}$, whereas that for 2-methylcitrate was approximately $3.3 \mathrm{mM}$. However, the maximum velocity for both the substrates was similar (Fig. 1). The addition of $0.2 \mathrm{mM}$ 2-methylcitrate inhibited the tricarboxylate carrier only at citrate concentrations which were close to the apparent $\mathrm{K}_{\mathrm{m}}(0.2 \mathrm{mM})$, whereas this inhibition was no longer significant when the citrate concentration was 10fold higher (Table 2).

\section{DISCUSSION}

2-Methylcitrate was observed in the urine in patients with propionic acidemia (1). The synthesis of 2-methylcitrate appears to be the consequence of propionyl-CoA accumulation and subse-

Table 1. Effect of 2-methylcitrate on enzymes which interact with citrate or isocitrate

\begin{tabular}{|c|c|c|}
\hline Enzyme & Substrate & $\begin{array}{l}\text { Inhibition } \\
\mathrm{K}_{\mathrm{i}}, \mathrm{mM}\end{array}$ \\
\hline Aconitase & cis-Aconitate & $4.0^{1}$ \\
\hline \multirow[t]{2}{*}{ Citrate synthase } & Acetyl-CoA & 2.0 \\
\hline & Oxaloacetate & 7.6 \\
\hline ATP-citrate lyase ${ }^{2}$ & Citrate & $\begin{array}{l}\text { No effect up } \\
\text { to } 5 \mathrm{mM}\end{array}$ \\
\hline $\begin{array}{l}\text { Isocitrate dehydrogenase, } \\
\text { NADP }^{+} \text {linked (mitochon- } \\
\text { drial) }\end{array}$ & Isocitrate & 1.8 \\
\hline $\begin{array}{l}\text { Isocitrate dehydrogenase, } \\
\text { NADP }+ \text { linked (extramito- } \\
\text { chondrial) }\end{array}$ & Isocitrate & 1.6 \\
\hline $\begin{array}{l}\text { Isocitrate dehydrogenase, } \\
\mathrm{NAD}^{+} \text {linked }\end{array}$ & Isocitrate & 6.0 \\
\hline Acetyl-CoA carboxylase & Acetyl-CoA & $0^{3}$ \\
\hline Phosphofructokinase & Fructose-6- $\mathrm{PO}_{4}$ & $\begin{array}{l}50 \% \text { inhibition by } \\
1 \mathrm{mM}\end{array}$ \\
\hline Pyruvate dehydrogenase & Pyruvate & $\begin{array}{l}\text { No inhibition up } \\
\text { to } 4.5 \mathrm{mM}\end{array}$ \\
\hline
\end{tabular}

\footnotetext{
${ }^{1}$ All inhibitions were competitive except this one, which was noncompetitive.

2-Methylcitrate is not a substrate for this enzyme.

${ }^{3}$ Acetyl-CoA carboxylase was activated by 2 -methylcitrate $\left(\mathrm{K}_{\mathrm{a}}=2.8\right.$ $\mathrm{mM})$.
} 
Table 2. Effect of 2-methylcitrate on mitochondrial citrate transporter ${ }^{1}$

\begin{tabular}{ccc}
\hline \multicolumn{2}{c}{ Additions } & \\
\cline { 1 - 2 } $\begin{array}{c}\text { Citrate, } \\
\mathrm{mM}\end{array}$ & $\begin{array}{c}\text { 2-Methylcitrate, } \\
\mathrm{mM}\end{array}$ & $\begin{array}{c}\text { Supernatant, } \\
\mathrm{dpm}^{2}\end{array}$ \\
\hline 0.2 & 0 & 21,697 \\
0 & 0.2 & 4,116 \\
0.2 & 0.2 & 19,420 \\
2.0 & 0 & 40,803 \\
2.0 & 0.2 & 39,732 \\
\hline
\end{tabular}

${ }^{1}$ Rat liver mitochondria $(4.0 \mathrm{mg})$ were added to $1 \mathrm{ml}$ of $20 \mathrm{mM}$

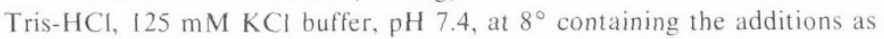
noted. After $1 \mathrm{~min}, 50 \mathrm{mM}$ 1,2,3-tricarboxybenzene was added for the inhibitor stop technique. The mitochondria were separated by rapid centrifugation and a portion of the supernatant was prepared for counting as described previously. The total counts were 172,197 dpm and the supernatant fraction contained $38,746 \mathrm{dpm}$ in the absence of additions. Results are reported as the mean of three values for a representative experiment. The total number of experiments was nine. The mean percentage of inhibition was $24.5 \% \pm 5.5$ when the citrate concentration was $0.2 \mathrm{mM}$ and $-2.1 \% \pm 12.6$ when the citrate was $2.0 \mathrm{mM}$.

${ }^{2}$ Disintegrations per min in supernatant after additions minus disintegrations per min in supernatant in the absence of tricarboxylate additions.

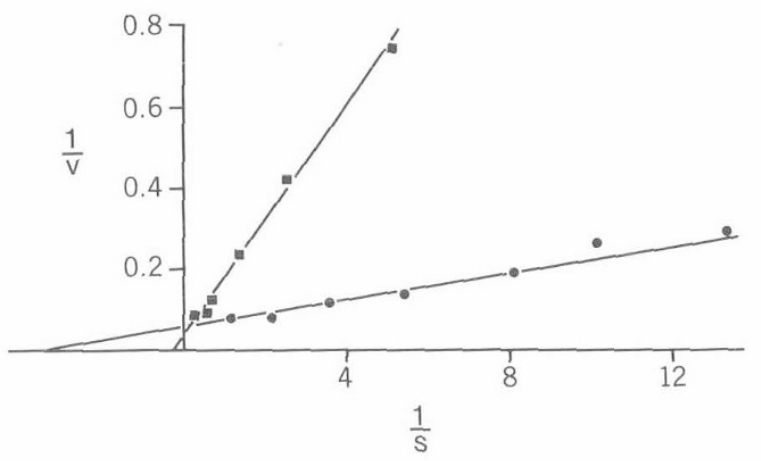

Fig. 1. Rate of exit of intramitochondrial $\left[{ }^{14} \mathrm{C}\right]$ citrate was studied as described in Methods. Mitochondria (3.7 $\mathrm{mg}$ and $4.8 \mathrm{mg}$, respectively) were incubated with $\left[{ }^{12} \mathrm{C}\right]$ citrate $(9$ ) or 2-methylcit rate ( the medium. The incubation was carried out at $8^{\circ}$ and 1,2,3-tricarboxybenzene was added after I min. The apparent $K_{m}$ for citrate was $260 \mu \mathrm{M}$ and the $V_{\max }$ was $0.5 \mathrm{nmol} / \mathrm{mg} / \mathrm{min}$. The apparent $\mathrm{K}_{\mathrm{m}}$ for 2 -methylcitrate was $3.3 \mathrm{mM}$ and the $\mathrm{V}_{\max } 0.3 \mathrm{nmol} / \mathrm{mg} / \mathrm{min}$.

quent condensation with oxaloacetate catalyzed by citrate synthase. Although this enzyme is almost specific for acetyl-CoA (26), the enzyme from pig heart can use propionyl-CoA (26) as substrate but only at about $0.1 \%$ of the maximum rate observed with acetyl-CoA (26). 2-Methylcitrate might accumulate in mitochondria at levels high enough to affect the enzymes involved with citrate metabolism (Scheme 1). As discussed by Ando et al. (1), it is possible that another enzyme could be responsible for 2-methylcitrate synthesis.

It will be assumed for the remainder of the discussion that the crystalline form of 2-methylcitrate represents the physiologic species, as the oil form (which probably represents stereoisomers of 2-methylcitrate) had almost no significant effects on the enzymes and transporter involved in citrate metabolism. 2-Methylcitrate might accumulate in the mitochondrion as a result of the high $\mathrm{K}_{m}$ for 2-methylcitrate for the mitochondrial citrate transporter (Fig. 1). The metabolic consequence of accumulation of 2-methylcitrate within the mitochondrion can be hypothesized from the data in Table 1. Inhibition of the enzymes of the citric acid cycle, citrate synthase, aconitase, and isocitrate dehyrogenase,

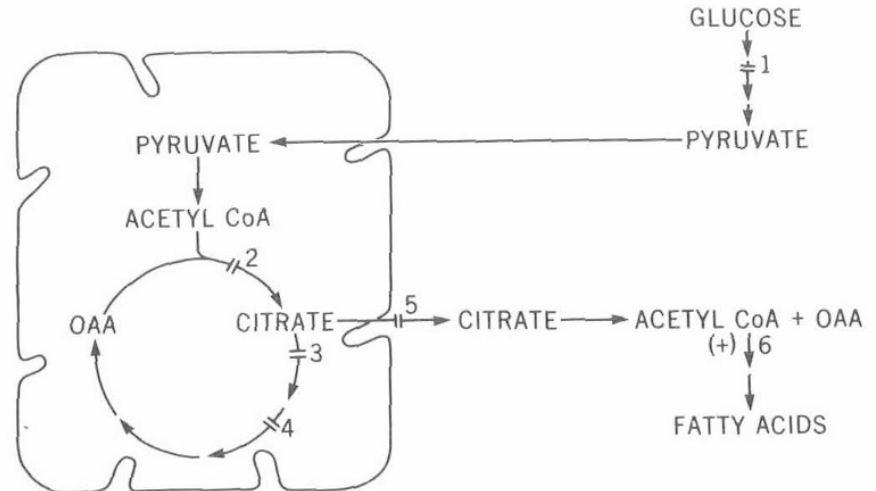

MITOCHONDRION

CYTOSOL

Scheme 1. Site of effects of 2-methylcitrate. 1: phosphofructokinase; 2: citrate synthase; 3: aconitase; 4: isocitrate dehydrogenase (NAD and $\mathrm{NADP}^{+}$linked); 5: mitochondrial citrate transporter; 6: acetyl-CoA carboxylase ( \pm , activation). $O A A$ : oxaloacetic acid.

will lead to accumulation of acetyl-CoA. As a consequence, the acetyl-CoA/CoA-SH will increase and thereby result in increased ketone body synthesis (for review, see Reference 8). The accumulation of other acyl-CoA derivatives such as propionyl-CoA and methylmalonyl-CoA could further elevate the acetyl- $\mathrm{CoA} / \mathrm{CoA}-\mathrm{SH}$ by decreasing the free $\mathrm{CoA}-\mathrm{SH}$ content and result in increased rates of ketogenesis

As 2-methylcitrate accumulates in the mitochondrion the mitochondrial citrate transporter will be inhibited competitively. Citrate will thus rise in the mitochondria and fall in the cytosol. This could lead to a reduction in the rate of fatty acid synthesis and also lessen the citrate-induced inhibition of phosphofructokinase. Therefore, enhanced glycolysis could possibly contribute to the hypoglycemia reported in this condition $(12,20)$. Glycolysis would also be increased and gluconeogenesis inhibited if ATP were to fall as a result of inhibition of the citric acid cycle. The effects of 2-methylcitrate on the citrate transporter were similar to those reported for 2-ethylcitrate (22), namely that of competitive inhibition as well as a substrate of relatively low affinity.

As the mitochondrial 2-methylcitrate accumulates further, it will exit on the tricarboxylate carrier. 2-Methylcitrate will behave much like citrate in the cytosol, in that it is an activator of acetyl-CoA carboxylase and an inhibitor of phosphofructokinase (Table 1). In contrast to citrate, this compound is not a substrate for ATP-citrate lyase (Table 1). Therefore, the synthesis of odd chain length fatty acids, which is of importance in this condition ( 2 , $3,14,15$ ) would most likely result from exit of propionyl-CoA from the mitochondrion, probably as the carnitine derivative. 2-Methylcitrate could play an indirect role in the synthesis of odd chain length fatty acids by activating acetyl-CoA carboxylase (Table 1). Although not mentioned in the above discussion, the chelation of divalent cations by these carboxylic acids could also have profound metabolic effects.

\section{SUMMARY}

In summary, 2-methylcitrate accumulation inside the mitochondrion might lead to inhibition of the citric acid cycle and thereby contribute to the ketogenesis and hypoglycemia seen in these conditions. Treatment of such patients with alkali therapy would be advantageous with respect to the acidemia but also would cause a more rapid exit of 2-methylcitrate from the mitochondrion (6). Alkalinization with sodium citrate might be even more beneficial if this citrate could enter the liver and allow more rapid removal of 2-methylcitrate and methylmalonate from liver mitochondria (Fig. 1 and Reference 8). The increased cytosolic levels of these intermediates would facilitate more rapid diffusion to the extracellular space and eventual excretion in the urine. 


\section{REFERENCES AND NOTES}

1. Ando, T., Rasmussen, K., Wright, J. M., and Nyhan, W. L.: Isolation and identification of methylcitrate, a major metabolic product of propionate in patients with propionic acidemia. J. Biol. Chem., 247: 2200 (1972).

2. Barley, F. W., Sato, G. H., and Abeles, R. H.: An effect of vitamin $B_{12}$ deficiency in tissue culture. J. Biol. Chem., 247: 4270 (1972).

3. Cardinale, G. J., Carty, T. J., and Abeles, R. H.: Effect of methylmalonyl coenzyme $\mathrm{A}$, a metabolite which accumulates in vitamin $\mathrm{B}_{12}$ deficiency on fatty acid synthesis. J. Biol. Chem., 245: 3771 (1970).

4. Chappell, J. B.: Systems used for the transport of substrates into mitochondria. Brit. Med. Bull., 24: 150 (1968).

5. Cheema-Dhadli, S., Halperin, M. L., and Leznoff, C. C.: Inhibition of enzymes which interact with citrate by (-)hydroxycitrate and 1,2,3-tricarboxybenzene. Eur. J. Biochem., 38: 98 (1973).

6. Cheema-Dhadli, S., Halperin, M. L., and Robinson, B. H.: Unpublished observations.

7. Fritz, I. B., Cheema-Dhadli, S., Taylor, W. M., Morris, H. P. and Halperin, M L.: Inhibition of hepatic fatty acid synthesis by long chain acyl CoA derivatives: Role of the mitochondrial citrate transporter. Alfred Benzon Symp., 6: 645 (1974).

8. Fritz, I. B., and Lee, L.: Fat mobilization and ketogenesis. In: D. F. Steiner and N. Freinkel: Handbook of Physiology: Endocrinology, Vol. I, p. 579 (The Williams \& Wilkins Co., Baltimore, 1972).

9. Goodridge, A. G.: Regulation of the activity of acetyl coenzyme A carboxylase by palmitoyl coenzyme A and citrate. J. Biol. Chem., 247:6946 (1972).

10. Habicht, E., and Schneeberger, P.: Synthese einiger substituiester citronensaüren. Helv. Chim. Acta, 39: 1316 (1956).

11. Halperin, M. L.. Cheema-Dhadli, S., Taylor, W. M., and Fritz, I. B. Role of the citrate transporter in the control of fatty acid synthesis. Advan. Enzyme Regul., 13: 435 (1975).

12. Halperin, M. L., Robinson, B. H., and Fritz, I. B.: Effects of palmitoyl CoA on citrate and malate transport by rat liver mitochondria. Proc. Nat. Acad. Sci. U. S. A., 69: 1003 (1972).

13. Halperin, M. L., Schiller, C. M., and Fritz, I. B.: The inhibition by methylmalonic acid of malate transport by the dicarboxylate carrier in rat liver mitochondria. J. Clin. Invest., 50:2276 (1971).

14. Hommer, F. A., Kuipers, J. R. G., Elema, J. D., Jansen, J. T., and Jonxis, J. H. P.: Propionicacidemia, a new inborn error of metabolism. Pediat. Res., 2: 519 (1968).

15. Kishimoto, Y., Williams, M., Moser, H. W. Hignite, C., and Biemann, K. Branched-chain and odd-numbered fatty acids and aldehydes in the nervous system of a patient with deranged vitamin $B_{12}$ metabolism. J. Lipid Res., 14 : 69 (1973).

16. Lowenstein, A., and Roberts, J. D.: The ionization of citric acid studied by the nuclear magnetic resonance technique. J. Amer. Chem. Soc. 82:2705 (1960).

17. Lowenstein, J. M.: Citrate and the conversion of carbohydrate into fat. Biochem. Soc. Symp., 27: 61 (1968).

Copyright (c) 1975 International Pediatric Research Foundation, Inc.
18. Lowry, O. H., Rosebrough, N. J., Farr, A. L., and Randall, R. J.: Protein measurement with the Folin phenol reagent. J. Biol. Chem., 193: 265 (1951).

19. Moellering. H., and Gruber, W.: Determination of citrate with citrate lyase. Anal. Biochem., 17:369 (1966).

20. Numa, S., Bortz, W. M., and Lynen, F.: Regulation of fatty acid synthesis at the acetyl-CoA carboxylase step. Advan. Enzyme Regul., 3: 407 (1967).

21. Oberholzer, V. G., Levin, B., Burgess, E. A., and Young W. F.: Methylmalonic aciduria, an inborn error of metabolism leading to chronic metabolic acidosis. Arch. Dis. Childhood, 42: 492 (1967).

22. Robinson, B. H. Williams, G. R., Halperin, M L and Leznoff, C. C. The effects of 2-ethylcitrate and tricarballylate on citrate transport in rat liver mitochondria and fatty acid synthesis in rat white adipose tissue. Eur. J. Biochem., 15: 263 (1970).

23. Robinson, B. H., Williams, G. R., Halperin, M. L., and Leznoff, C. C: The sensitivity of the exchange reactions of tricarboxylate, 2-oxoglutarate and dicarboxylate transporting systems of rat liver mitochondria to inhibition by 2-pentylmalonate, p-iodobenzylmalonate and benzene 1,2,3-tricarboxylate. Eur. J. Biochem., 20: 65 (1971)

24. Robinson, B. H., Williams, G. R., Halperin, M. L., and Leznoff, C. C.: Factors affecting the kinetics and equilibrium of exchange reactions of the citrate-transporting system of rat liver mitochondria. J. Biol. Chem., 246: 5280 (1972)

25. Schiller, C. M., Taylor, W. M. and Halperin, M. L. Control of fatty acid synthesis in white adipose tissue by insulin: Coordination between mitochondrial citrate transporter and pyruvate dehydrogenase. Can. J. Biochem., 52. 813 (1974).

26. Stern, J. R.: Oxalacetate transacetase (condensing enzyme, citrogenase). In: P. D Boyer, H. Lardy, and K. Myrbäck: The Enzymes, Vol. V, p. 367 (Academic Press, New York, 1961).

27. Taylor, W. M., and Halperin, M. L.: Regulation of pyruvate dehydrogenase in muscle: Inhibition by citrate. J. Biol. Chem., 248: 6080 (1973).

28. High Oak Ranch, Goodwood, Ontario.

29. New York, N. Y.

30. St. Louis, Mo.

31. Plainview, N. Y.

32. Don Mills, Ontario.

33. The authors are very grateful for the expert technical assistance of Ms. Barbara Green and Ms. Marina Leung and to Drs. I. B. Fritz, Brian Robinson, Frances Rolleston, and Wayne Taylor for helpful advice and discussions.

34. Dr. M. L. Halperin is recipient of Grant MT 3363 from the Medical Research Council of Canada.

35. This research was supported in part by St. Micheal's Research Society and the Banting Research Foundation.

36. Requests for reprints should be addressed to: S. Cheema-Dhadli, Ph.D., Rm. 7363. Medical Sciences Bldg., University of Toronto, Toronto, Ontario M5S IA8 (Canada).

37. Accepted for publication July 25, 1975
Brain fibroblasts liver

\title{
Sphingomyelinases in Human Tissues. II. Absence of a Specific Enzyme from Liver and Brain of Niemann-Pick Disease, Type $\mathrm{C}$
}

\author{
J. W. CALLAHAN ${ }^{(31)}$ AND M. KHALIL \\ Research Institute, Hospital for Sick Children, Toronto Ontario, Canada
}

M. PHILIPPART

Neuropsychiatric Institute, UCLA, Los Angeles, California, USA

Extract

Sphingomyelinase was obtained in excellent yield from liver and brain by homogenization with $0.05 \mathrm{M}$ citrate-phosphate buffer, $\mathrm{pH}$
4.5, containing $0.25 \%$ Triton $X-100(v / v)$ followed by dialysis of the supernatant fluids against $1 \%$ glycine. Total recovery of enzyme was slightly less with tissue from Niemann-Pick disease compared with control tissue. 